\title{
Experiences of violence at school from the stuttering patients' perspective
}

Marina Pelingrin Zamprogno ${ }^{1}$ https://orcid.org/0000-0002-3672-6802

Patrícia Pupin Mandrá 1 https://orcid.org/0000-0002-2926-0354

Tatiane Cristina Gonçalves ${ }^{1}$ https://orcid.org/0000-0002-3074-3716

Tatiane Martins Jorge ${ }^{1}$ https://orcid.org/0000-0002-1017-6865
Universidade de São Paulo, Faculdade de Medicina, Departamento de Ciências da Saúde, Ribeirão Preto, São Paulo, Brasil.

Conflict of interests: Nonexistent

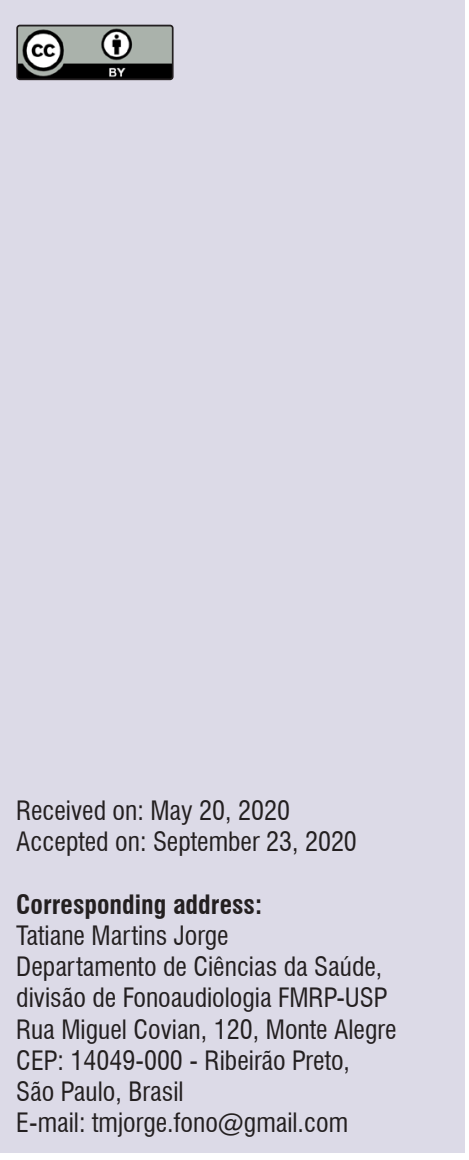

\section{ABSTRACT}

Purpose: to characterize school-aged patients with persistent stuttering regarding their self-reported experiences of violence at school.

Methods: the sample comprised 10 patients with persistent stuttering, 10 to 17 years old, regardless of their sex and stuttering characteristics, who received care at a fluency outpatient center in the heart of São Paulo State, Brazil. The collection instrument was an 11-question, multiple-choice, self-administered questionnaire. The data were descriptively analyzed based on the frequency of the answers.

Results: almost half of the stuttering patients reported suffering bullying, in which they were given nicknames, defamed, blamed for everything that happened, physically attacked, and mocked. The classroom was the most mentioned environment where bullying took place. The following reactions to violence were mentioned: "talking to friends, teachers/principals, and relatives", "sadness", and "desire to change schools". Conclusion: despite the small sample size, it was possible to note alarming data and the importance of educative/preventive actions in the school environment, approaching both bullying and stuttering.

Keywords: Stuttering; Bullying; Students 


\section{INTRODUCTION}

Bullying is a term used to describe either direct (physical) or indirect violent behaviors that take place in the school environment ${ }^{1-3}$. Bullying is made up of three elements: intention, repetition, and power imbalance ${ }^{1,4}$. Violent behavior is considered bullying when it occurs more than once a month 5 .

This type of intentional, repetitive, and persistent violence is directed against weaker people, without any apparent reason ${ }^{1,2}$. Violent behavior can involve nicknames, rejection, provocations, and even beatings ${ }^{6}$. The most frequent type of bullying is verbal, followed by social, physical, and virtual (Internet) ${ }^{7}$.

It is quite evident that all victims of bullying suffer from aggression to a greater or lesser degree. Many people bear the marks of such suffering until they are adults, possibly needing psychological and/or psychiatric follow-up ${ }^{2}$. The most common consequences to the victims of bullying are uninterest in school, frequent absences, difficulties having or making friends, feeling of loneliness ${ }^{8}$, difficulties getting asleep, nightmares ${ }^{9}$, behavioral problems, anorexia, bulimia, increased anxiety, psychic problems, depression, and so forth. In more serious and recurrent cases, suffering bullying can lead to suicidal ideations $s^{2,7,10}$.

The findings of the Pesquisa Nacional de Saúde do Escolar (PeNSE - National Student Health Research), which investigated Brazilian students that were either bullies or victims of bullying, indicated a higher rate of bullying among boys aged 11 to 14 years, and a lower rate in preschool and high school ${ }^{11}$.

A risk group for bullying is that of schoolers with a disability, such as communication difficulties or language disorders ${ }^{3,6,12,13}$. Stuttering people, for instance, are more likely to be victims of bullying than those who do not stutter ${ }^{3,5,14-17}$. Moreover, they are two times more likely to be victims of violent crimes than their peers ${ }^{13}$.

The characteristics observed in the speech of a stuttering person, such as repeated sounds or syllables, prolonged sounds, and interrupted and blocked words ${ }^{18}$, inhibit or hinder the child's verbal activities at school, increasing the possibility of rejection ${ }^{14}$.

The negative social consequences of stuttering can start in preschool and continue throughout their whole life ${ }^{19}$. The literature has revealed a prevalence of reports of bullying ranging from $26 \%$ to $61 \% 3,15,16,20$. Preschoolers consider it negative when a classmate stutters, whom they may ignore, interrupt, mock, and even avoid ${ }^{19}$. The difficulties grow more intense with the years at school since communication is increasingly important in the educational and social context.

Regarding the type of bullying they suffer, most of the teasing is more verbal than physical. Most of the time, the adolescents have their stuttering imitated ${ }^{20}$ or they are nicknamed ${ }^{3}$. As for the consequences of having suffered bullying, the following were mentioned: feeling anxious, sad, depressed, irritated, timid, embarrassed, and being unwilling to go to school and overall dissatisfied with life ${ }^{16}$.

Understanding stuttering beyond its clinical aspects is particularly important. The need for more scientific research in Brazil has been noticed, as well as the dissemination of stuttering patients' bullying-related experiences and feelings in the school environment. Based on such dissemination, educative and protective actions towards this risk group for bullying is expected to increase. This study aimed to characterize schoolage patients with persistent stuttering, who received care at an outpatient center in the heart of São Paulo State, Brazil, regarding their self-reported experiences of violence at school.

\section{METHODS}

The research began after the approval by the Human Research Ethics Committee of the Hospital das Clínicas da Faculdade de Medicina de Ribeirão Preto da Universidade de São Paulo - HCFMRPUSP, SP, Brazil (evaluation report number 2.358.935/CAAE 77105317.6.0000.5440). All the participants signed the informed consent form, as well as those legally responsible for them.

The inclusion criteria were: 1) presenting a diagnosis of stuttering, following Andrade's protocol ${ }^{21}$ for the assessment of speech fluency; 2) undergoing therapeutic follow-up at a fluency outpatient center in the municipality of Ribeirão Preto, São Paulo, Brazil; 3) being 10 to 17 years old; 4) attending school (middle or high school); 5) knowing how to read, according to self-reported information; 6) agreeing to participate in the study. Patients that were undergoing speechlanguage-hearing follow-up for any reason other than stuttering and those that did not want to participate were excluded.

The sample comprised 10 patients diagnosed with stuttering. Nine of them were boys, the youngest was 10 years old, and the oldest, 17 (mean 12.7 years). The predominant age group was 10 to 12 years old (60\%), followed by 13 to 15 years old (20\%), and 16 years old 
or more $(20 \%)$. Most of them attended public schools $(80 \%)$ and were in middle school $(80 \%)$.

The data were collected at the therapist's office, taking approximately the last 20 minutes of the appointment, using an 11-question self-administered questionnaire, developed based on the Brazilian Portuguese version ${ }^{22}$ of the original Training and Mobility of Researchers (TMR) questionnaire ${ }^{23}$. Of the 11 questions, five were open-ended and referred to the patient's personal data, and the other six were closedended and referred to their feelings and experiences of violence in the school environment, which is the object of this study. The closed-ended questions allowed the participant to answer with more than one option.

The answers to the questionnaire were tabulated in an Excel spreadsheet, and the data were descriptively analyzed based on the frequency of the answers.

\section{RESULTS}

The feelings of the stuttering patients towards the school and their schoolmates are shown in Table 1.

Table 1. Stuttering patients' feelings towards school, in absolute and relative numbers $(n=10)$

\begin{tabular}{lcc}
\hline ASPECTS INVESTIGATED & Absolute number (n) & Relative number (\%) \\
\hline How do you feel about school? & 2 & $20 \%$ \\
Very well. & 7 & $70 \%$ \\
Well. & 1 & $10 \%$ \\
Sometimes I don't feel well. & 0 & $0 \%$ \\
Very bad. I don't like it. & & \\
\hline How do you feel about your schoolmates? & 6 & $60 \%$ \\
I feel well and I have many friends. & 2 & $20 \%$ \\
I feel well with everyone, but no one in particular. & 2 & $20 \%$ \\
I feel well with two or three friends. & 0 & $0 \%$ \\
I almost don't have friends. & & \\
\hline In general, how are you treated by your schoolmates? & 4 & $40 \%$ \\
Very well. & 0 & $0 \%$ \\
Well. & 6 & $60 \%$ \\
Average. Neither well nor badly. & 0 & $0 \%$ \\
Badly. & &
\end{tabular}

The presence or absence of the sensation of having already been mistreated, threatened, or abused by schoolmates, as well as having already provoked or mistreated their peers, is described in Table 2.

Table 2. Characterization of violence at school, according to stuttering patients, in absolute and relative numbers $(n=10)$

\begin{tabular}{lcc}
\hline ASPECTS INVESTIGATED & Absolute number (n) & Relative number (\%) \\
\hline Do you feel any of your schoolmates abuses, mistreats, or & & \\
threatens you? & 4 & $40 \%$ \\
Yes & 6 & $60 \%$ \\
No & & \\
\hline Do you provoke or mistreat any of your schoolmates? & 1 & $10 \%$ \\
Yes & 9 & $90 \%$ \\
No & & \\
\hline
\end{tabular}


Table 3 describes the demographic profile of stuttering schoolchildren that mentioned having been mistreated, threatened, or abused by schoolmates, as well as the characteristics of this type of violence.
The participants were also asked about possible measures to avoid violence at school, in case they were the principal. The results are described in Table 4.

Table 3. Characterization of the abuses mentioned by the participants, in absolute and relative numbers $(n=4)$

\begin{tabular}{|c|c|c|}
\hline ASPECTS INVESTIGATED & Absolute number (n) & Relative number (\%) \\
\hline \multicolumn{3}{|l|}{ Frequency } \\
\hline Once a month & 2 & $50 \%$ \\
\hline More than once a month & 1 & $25 \%$ \\
\hline Almost every day & 1 & $25 \%$ \\
\hline \multicolumn{3}{|l|}{ Age of those who suffered violence* } \\
\hline $10-13$ years & 2 & $50 \%$ \\
\hline $14-15$ years & 2 & $50 \%$ \\
\hline \multicolumn{3}{|l|}{ Sex of those who suffered aggression } \\
\hline Boys & 3 & $75 \%$ \\
\hline Girls & 1 & $25 \%$ \\
\hline \multicolumn{3}{|l|}{ Who was the aggressor } \\
\hline Only boy(s) & 3 & $75 \%$ \\
\hline Only girl(s) & 0 & $0 \%$ \\
\hline Both boy(s) and girl(s) & 1 & $25 \%$ \\
\hline \multicolumn{3}{|l|}{ Type of aggression } \\
\hline Giving nicknames & 1 & $25 \%$ \\
\hline Blaming for everything that happened & 3 & $75 \%$ \\
\hline Defamation ("act of saying bad things about someone") & 2 & $50 \%$ \\
\hline Physical attacks & 1 & $25 \%$ \\
\hline Mocking & 1 & $25 \%$ \\
\hline \multicolumn{3}{|l|}{ Place where the aggression occurred } \\
\hline Classroom & 4 & $75 \%$ \\
\hline Schoolyard & 1 & $25 \%$ \\
\hline \multicolumn{3}{|l|}{ What motivated the aggression } \\
\hline To make fun/tease & 2 & $50 \%$ \\
\hline Because they had a hard time speaking or took too long to speak & 1 & $25 \%$ \\
\hline Because they were weaker than others or were different from them & 1 & $25 \%$ \\
\hline To retaliate & 1 & $25 \%$ \\
\hline Did not know the reason & 2 & $50 \%$ \\
\hline \multicolumn{3}{|l|}{ Reaction to the aggression } \\
\hline Talk to their friends about what happened & 1 & $25 \%$ \\
\hline Talk to the teacher/principal & 3 & $75 \%$ \\
\hline Talk to the family & 1 & $25 \%$ \\
\hline Get sad & 1 & $25 \%$ \\
\hline Ask to change school & 1 & $25 \%$ \\
\hline \multicolumn{3}{|l|}{ Who intervened in the aggression } \\
\hline A schoolmate & 2 & $50 \%$ \\
\hline A teacher & 1 & $25 \%$ \\
\hline A relative & 0 & $0 \%$ \\
\hline Another person & 0 & $0 \%$ \\
\hline No one intervened & 1 & $25 \%$ \\
\hline
\end{tabular}

${ }^{*}$ mean age $=13$ years; median $=13.5$ years 
Table 4. Preventive measures mentioned by stuttering patients, in absolute and relative numbers $(n=10)$

\begin{tabular}{lcc}
\hline ASPECTS INVESTIGATED & Absolute number (n) & Relative number (\%) \\
\hline If you were the school principal, what would you do to avoid & & \\
violence at school? & 4 & $40 \%$ \\
Install cameras/increase vigilance/search students & 5 & $50 \%$ \\
Give educative speeches & 3 & $30 \%$ \\
Punish those involved, either suspending or expelling them & 2 & $20 \%$ \\
Invest in leisure and sports areas, and cultural activities & 8 & $80 \%$ \\
Talk to the students and their families & & \\
\hline
\end{tabular}

\section{DISCUSSION}

Concerning the school-related feelings, although most of the stuttering schoolchildren mentioned they "felt well" or "very well" and had many friends, the quality of the interaction was considered average. Likewise, in the study by Nagib et al. ${ }^{3}$, most of the subjects stated they felt very well at school and with friends. In the school environment, bonding with peers is a protective factor against the serious forms of bullying ${ }^{9}$, as they build mutual confidence when facing challenges that help them overcome their vulnerability. For this reason, the number of friends and the quality of their interactions must be always investigated by relatives, and school and health professionals.

Regarding the sensation of violence in the school environment, almost half of the schoolchildren reported the sensation of abuses, mistreatments, or threats. This finding agrees with other studies that showed that schoolers that stutter or have another communication difficulty are more likely to suffer bullying than those without such impairments ${ }^{3,6,12-14}$. As for the four participants that reported being victims of violence, half of them stated that this practice occurred more than once a month, which can be characterized as bullying. An important aspect to highlight is that such frequency may have been underreported, as, for many students, violence is already a natural, integral part of school life ${ }^{24}$.

Those who reported suffering from school violence were from 10 to 15 years old, mean 13 years. Research reports that bullying takes place increasingly less often as they grow older and advance in school grades, $6,-10$ when they are 16, 17 years old, the students tend not to suffer bullying, whereas when they are 13 years old or younger, they are more likely to suffer such violence ${ }^{8,11}$. This can be explained by their increase in physical strength and cognitive and social gain that result from growing up, which decreases their vulnerability and improves their coping strategies ${ }^{8}$.

These stuttering schoolchildren that suffered violence were mainly given nicknames, defamed, and blamed for everything that happened. Being given nicknames was also reported in another study ${ }^{3}$, reinforcing that most of the violence is verbal ${ }^{7}$.

Also, in the present research, most of the violence took place in the classroom, followed by the schoolyard. This corroborates the study by Lopes $\mathrm{Neto}^{25}$, which reports that the classroom was the environment mentioned by more than half of the students that suffer bullying in Brazil. On the other hand, in the study by Santos and Kienen ${ }^{26}$, the place where most of the bullying took place was the schoolyard, followed by the classroom.

In the present study, violence was motivated by the desire to "make fun/tease", or because "they had a hard time speaking", "they took too long to speak", "they were weaker than the others", or "they were different from the others". Hence, it is noticed that stuttering is a motivating factor for bullying ${ }^{3}$. The reluctance or difficulty to participate in verbal activities can affect their social interaction and the manner how they are seen by their peers, who oftentimes label these schoolchildren as timid or introvert ${ }^{14}$. Being timid and having relationship difficulties, in their turn, are two characteristics perceived in the victims of bullying ${ }^{5}$.

Concerning the reactions of those who reported suffering bullying, "talking to the teacher/principal" was frequently mentioned, unlike what was described in the researched literature ${ }^{20,25}$. On the other hand, in the present study, the teacher was little mentioned as the person who intervened in cases of violence, which can suggest unaware, unprepared, or uninvolved teachers in the fight against victimization due to bullying 9 . The role of intervening when violence occurred was given to the friends, which once again reinforces the importance of strengthening the support network among 
schoolchildren, with or without communication difficulties, with the help of parents, teachers, and health professionals.

This study also pointed out that four out of 10 schoolage stuttering patients reported episodes of violence at school, which reinforces the need to seriously broaden the educative actions at school, engaging teachers, schoolmates, and parents ${ }^{6,14}$, especially in middle school. Not only victims but also bullies and spectators must be involved in the discussion around this theme and that of management of thoughts and feelings that motivate bullying ${ }^{27}$. As for stuttering, it is essential to instruct the schoolchildren about the condition, making them feel it and think about it, and include in the activities those with communication difficulties, teaching them to use assertive responses when intimidated. It is also necessary to teach their schoolmates and spectators about the relationship between stuttering and bullying, for them to be attentive to it, and instruct administrators and parents that bullying is the problem, not stuttering ${ }^{28}$.

Assistive, preventive, and/or educative actions in the school environment targeting students, teachers, and administrators have been described as effective in the fight against bullying, able to achieve a relevant reduction in victimizations ${ }^{9}$. Investing in actions to discuss and implement strategies to fight bullying is the whole community's duty since this type of violence is a public health issue, which does not affect the student alone. It is academia's role to invest in research to help develop and implement these strategies in various contexts ${ }^{4}$.

A limitation of the study was the small sample size of stuttering preadolescents and adolescents undergoing speech-language-hearing follow-up. This is to be expected, given that the first signs and symptoms of stuttering manifest in childhood ${ }^{29}$ when there is a greater demand for speech-language-hearing health care. Another limitation perceived regarding the sample was the use of a questionnaire instead of an interview, which might have furnished more qualitative information to the study. It is suggested that further studies be carried out focused on the bullying of students that stutter or have other communication disorders.

\section{CONCLUSION}

In this study, although the stuttering patients felt well at school and had many friends, the quality of the interaction with their peers was considered average. Almost half mentioned they had the sensation of being abused, mistreated, or threatened at school, especially in the classroom and with verbal attacks. Having communication difficulties and being considered weaker than their peers were some of the motivations reported by those who suffered bullying.

These findings reinforce the need for additional study on the theme and the importance of the speechlanguage-hearing therapists' investment in their own social role of instructing the population about stuttering and bullying, inside and outside the therapists' office.

\section{REFERENCES}

1. Olweus D, Limber SP. Bullying in school: evaluation and dissemination of the Olweus Bullying Prevention Program. Am J Orthopsychiatry. 2010;80(1):124-34.

2. Silva ABB. Bullying: Cartilha 2010 - Projeto Justiça nas Escolas. Brasília/DF: Conselho Nacional de Justiça, 2010.

3. Nagib L, Mousinho R, Salles GFCM. Caracterização do bullying em estudantes que gaguejam. Rev Psicopedagogia. 2016;33(102):235-50.

4. Thornberg R, Hunter SC, Hong JS, Ronnberg J. Bullying among children and adolescents (editorial). Scand J Psychol. 2020;61(1):1-5.

5. Moura DR, Cruz ACN, Quevedo LA. Prevalence and characteristics of school-age bullying victims. $J$ Pediatr. 2011;87(1):19-23.

6. Garmy $P$, Vilhjálmsson R, Kristjánsdóttir G. Bullying in school-aged children in Iceland: a cross-sectional study. J Pediatr Nurs. 2018;38(1):e30-e34.

7. Ashraf IA, Feng CX, Neudorf $C$, Alphonsus KB. Bullying victimization among preadolescents in a community-based sample in Canada: a latent class analysis. BMC Res Notes. 2020;13(1):138.

8. Silva JL, Mello FCM, Oliveira WA, Prado RR, Silva MAI, Malta DC. Bullying victimization among Brazilian students: results of the national survey of school health (PeNSE). Texto Contexto Enferm. 2018;27(3):e0310017.

9. Vieira Junior FU, Vieira KMR, Moretti AC. Bullying com adolescentes escolares em diferentes contextos educacionais. Rev enferm UFPE. 2020;14(1):e243622.

10. Wanga GF, Hana AZ, Zhanga GB, Xua N, Xiea GD, Chena LR et al. Sensitive periods for the effect of bullying victimization on suicidal behaviors among university students in China: the roles of timing and chronicity. J Affect Disord. 2020;268:12-19. 
11. Malta DC, Porto DL, Crespo CL, Silva MMA, Andrade SSC, Mello FCM et al. Bullying in Brazilian schoolchildren: analysis of the National Adolescent School-based Health Survey (PeNSE 2012). Rev Bras Epidemiol. 2014;17(Suppl 1):92-105.

12. Beitchman J, Brownlie E. Language development and its impact on children's psychosocial and emotional development. In: Tremblay R, Barr R, Peters R (eds). Encyclopedia on early childhood development. Montreal,Quebec: Centre of Excellence for Early Childhood Development and StrategicKnowledge. Retrieved from. http://www.child-encyclopedia.com/languagedevelopment-and-literacy/according-experts/ language-development-and-its-impact-childrens

13. Christoffersen MN. Violent crime against children with disabilities: a nationwide prospective birth cohort-study. Child Abuse Neglect. 2019;98:104150.

14. Davis S, Howell P, Cooke F. Sociodynamic relationships between children who stutter and their non-stuttering classmates. J Child Psychol Psychiatry. 2002;43(7):939-47.

15. Blood GW, Blood IM. Preliminary study of self-reported experience of physical aggression and bullying of boys who stutter; relation to increased anxiety. Percept Mot Skills. 2007;104(3 Pt 2):1060-6.

16. Blood GW, Blood IM, Tramontana GM, Sylvia AJ, Boyle MP, Motzko GR. Self-reported experience of bullying of students who stutter: relations with life satisfaction, life orientation, and self-esteem. Percept Mot Skills. 2011;113(2):353-64.

17. Blood GW, Blood IM. Long-term consequences of childhood bullying in adults who stutter: social anxiety, fear of negative evaluation, self-esteem, and satisfaction with life. J Fluency Disord. 2016;50:72-84.

18. Manual diagnóstico e estatístico de transtornos mentais [recurso eletrônico]: DSM-5 / [American Psychiatric Association; tradução: Nascimento MIC, Machado PH, Garcez RM, Pizzato R, Rosa SMM]; revisão técnica: Cordioli AV, Kieling C, Silva CTB, Passos IC,Barcellos MR. 5. ed. Dados eletrônicos. Porto Alegre: Artmed; 2014.

19. Iverach L, Jones M, McLellan LF, Lyneham HJ, Menzies RG, Onslow M et al. Prevalence of anxiety disorders among children who stutter. J Fluency Disord. 2016;49:13-28.
20. Erickson S, Block S. The social and communication impact of stuttering on adolescents and their families. J Fluency Disord. 2013;38(4):311-24.

21. Andrade CRF. Protocolo para avaliação da fluência da fala. Pró-Fono R Atual Científ. 2000;12(2):131-4.

22. De Aquino CRB. Acesso escolar, violência entre iguais, alunos versus alunos em quatro escolas municipais de Salvador, Bahia, Brasil [Tese]. Salamanca (Espanha): Universidade de Salamanca, Faculdade de Educação, Departamento de Teoria e História da Educação; 2010.

23. Ortega R, Mora-Merchán JA, Singer $M$, Smith PK, Pereira B, Menesint E. The general survey questionnaires and nomination methods concerning bullying. Final report presented at IV Meeting of TMR project: Nature and Prevention of Bullying and Social Exclusion. Munich; 1999.

24. Oliveira WA, Silva JL, Braga IF, Romualdo C, Caravita SCS, Silva MAI. Ways to explain bullying: dimensional analysis of the conceptions held by adolescents. Ciênc saúde coletiva. 2018;23(3):751-61.

25. Lopes Neto AA. Bullying - aggressive behavior among students. J Pediatr. 2005;81(5):S164-72.

26. Santos MM, Perkoski IR, Kienen N. Bullying: atitudes, consequências e medidas preventivas na percepção de professores e alunos do ensino fundamental. Temas Psicol. 2015;23(4):1017-33.

27. Walters GD. School-age bullying victimization and perpetration: a meta-analysis of prospective studies and research. Trauma, violence, abuse. 2020;21:1-11.

28. Yaruss JS, Reeves N, Herring C. How speechlanguage pathologists can minimize bullying of children who stutter. Semin Speech Lang. 2018;39(4):342-55.

29. Andrade CRF. Abordagem neurolinguística e motora da gagueira. In: Fernandes FDM, Mendes BCAM, Navas ALPGP (orgs). Tratado de Fonoaudiologia. São Paulo: Roca, 2009. p. 423-53. 